\title{
NACHHALTIGE ENERGIEVERSORGUNG MOBILER ARBEITSMASCHINEN
}

Die steigende Weltbevölkerung und das Wirtschaftswachstum lassen die Nachfrage nach Energie zukünftig weiter steigen. Um dieser Entwicklung beizukommen, reichen die Lösungen von einer immer tieferen Suche nach Ressourcen fossiler Energieträger bis hin zur Entwicklung neuer Energieversorgungssysteme. Weiterhin versucht die Politik durch gesetzliche Rahmenbedingungen den Weg zu einer auf erneuerbaren Energieträgern basierten Energieversorgung zu ebnen. Das vorliegende Szenario stellt einige Lösungen für die nachhaltige Energieversorgung mobiler Arbeitsmaschinen vor, welches am Lehrstuhl für Mobile Arbeitsmaschinen des KIT ausgearbeitet wurde.
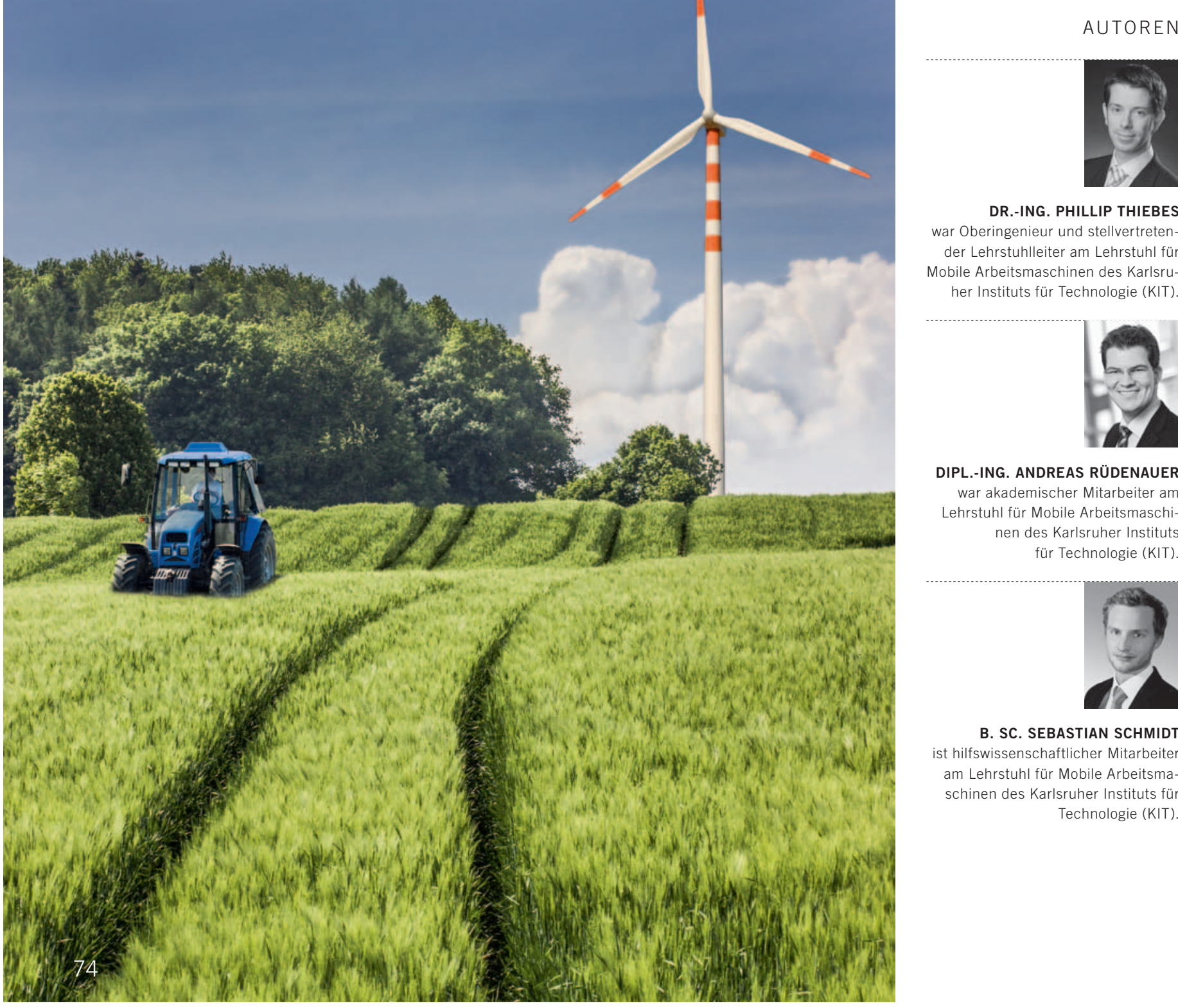

DR.-ING. PHILLIP THIEBES war Oberingenieur und stellvertretender Lehrstuhlleiter am Lehrstuhl für Mobile Arbeitsmaschinen des Karlsruher Instituts für Technologie (KIT).

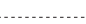

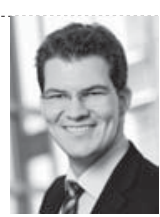

DIPL.-ING. ANDREAS RÜDENAUER war akademischer Mitarbeiter am Lehrstuhl für Mobile Arbeitsmaschinen des Karlsruher Instituts für Technologie (KIT).

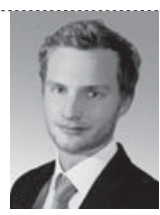

B. SC. SEBASTIAN SCHMIDT ist hilfswissenschaftlicher Mitarbeiter am Lehrstuhl für Mobile Arbeitsmaschinen des Karlsruher Instituts für Technologie (KIT) 


\section{SYSTEMGRENZEN FÜR DIE BEWERTUNG VON ANTRIEBSKONZEPTEN}

Um klimapolitischen Zielen und den preislichen Entwicklungen der erschöpfbaren, konventionellen Energieversorgung zu genügen, werden im Bereich der mobilen Arbeitsmaschinen neue Antriebskonzepte diskutiert. Ziel ist es hierbei, den Weg zu einer auf erneuerbaren Energieträgern basierten Energieversorgung zu ebnen, um zukünftig absehbare $\mathrm{CO}_{2}$-Emissionsgrenzen zu erreichen und hohen Mineralölpreisen auszuweichen. In dieser Studie werden unterschiedliche Lösungen für die nachhaltige Energieversorgung mobiler Arbeitsmaschinen, ausgehend vom Status quo, gesucht und ein Szenario für das Jahr 2050 entwickelt. Hierfür werden Kriterien der Nachhaltigkeit definiert und auf die heutigen und zukünftig möglichen Energieversorgungssysteme angewandt. Bereits heute haben elektrifizierte Antriebe lokal keine $\mathrm{CO}_{2}$-Emissionen. Wohl aber fallen solche Emissionen bei der Stromerzeugung an. Eine Tank-towheel-Analyse griffe folglich zu kurz. Aufgrund dieser Einsicht wird an dieser Stelle eine ganzheitliche Betrachtung im Sinne einer Well-to-wheel-Analyse gewählt, um eine bessere Vergleichbarkeit zwischen den emissionsfreien und emissionsbehafteten Energieversorgungssystemen zu gewährleisten. Eine Übersicht über die allgemeinen Systemgrenzen bietet 1 [1], welches auf der horizontalen Achse den Lebensweg von Materialien und Bauteilen für das Fahrzeug darstellt und auf der vertikalen Achse deren zeitlicher Einsatz festgelegt wird. Aus diesem allgemeinen Well-towheel-Ansatz werden die Systemgrenzen für diese Studie und für mobile Arbeitsmaschinen wie folgt angepasst:

: Es werden verschiedene Energieversorgungssysteme miteinander verglichen, sodass die tatsächliche Nutzung im Sinne von Betriebszeiten auf der horizontalen Achse unerheblich ist. Die Energieversorgung gilt für vergleichbare Maschinen mit gleichen Betriebszeiten.

: Auf der Vertikalen wird der Zeitpunkt gesucht, an dem die Maschine eine Einheit Brennstoff beziehungsweise eine Einheit Energie verbraucht.

: Bei der Produktion von Material und Teilen wird nur die Produktion und Auf- bereitung des Brennstoffs betrachtet, nicht aber die Produktion der Technologien, die die finale Energieumsetzung auf die Getriebeeingangswelle vornehmen (zum Beispiel Otto- und Dieselmotor, Elektromotor) oder die Energie entlang des Pfades speichern (Batterien, Speicherkraftwerke etc.).

: Die Wirkungsgrade der Energiespeicher werden dort mit eingefügt, wo eine Speicherung aufgrund der fluktuierenden Verfügbarkeit der Energie notwendig ist.

: Insgesamt handelt es sich um eine Well-to-tank-Betrachtung inklusive der Energieumsetzung in der Antriebsmaschine (1) rot umrahmt), die Entsorgung wird nicht betrachtet.

\section{DEFINITION EINER NACHHALTIGKEITSKENNZIFFER}

Für einen Überblick der Energieversorgungssysteme sorgt die Ausarbeitung der Energiepfade. Die Energiepfade visualisieren die Vielfältigkeit von Energieerzeugungssystemen, (2. Ausgehend von fossilen und regenerativen Primärenergieträgern wandelt sich die Primärenergie entlang verschiedener Pfade und Verzweigungen in die finale Form von technischer Exergie an der Senke um (hier Verbrennungskraftmaschine, Elektromotor oder hybrides Antriebssystem). Der
Großteil der Energiepfade konnte mit Daten aus der Datenbank ecoinvent abgebildet und bewertet werden. Diese Datenbank stellt Daten zu mehreren tausend Prozessen aus der Industrie bereit, mit denen es möglich ist, den kompletten Lebenszyklus eines Produktes hinsichtlich der Energiebereitstellung, der Materialherstellung und -verarbeitung und der Transport- und Entsorgungsdienstleistungen zu bilanzieren (Life-CycleInventory, LCI) und zu bewerten (LifeCycle-Assessment, LCA). Die Datensätze sind pro Prozess sehr groß und erschweren durch die schiere Anzahl der Einträge die Bilanzierung, beispielsweise mit über 500 Einträgen bezüglich der Emissionen in die Luft. Die für die Energieerzeugungssysteme verwendete ReCiPe-Methode fasst diese Daten zusammen und kategorisiert diese beispielsweise nach deren globalen Erwärmungspotenzial. Die Rechenmethoden und genutzten Faktoren sind nachfolgend aufgeführt:

: Nachhaltiger Wirkungsgrad ( $\left.\eta_{\text {nachhaltig}}\right)$ : Bilanziert wird hierbei die Energiemenge des Endproduktes (durch den Heizwert oder Kilowattstunde Strom) und die benötigte Energiemenge, die entlang eines bestimmten Energiepfades zur Herstellung des Energieträgers anfällt. Ziel des Pfads ist der Tank. Multipliziert wird dieser Bruch mit

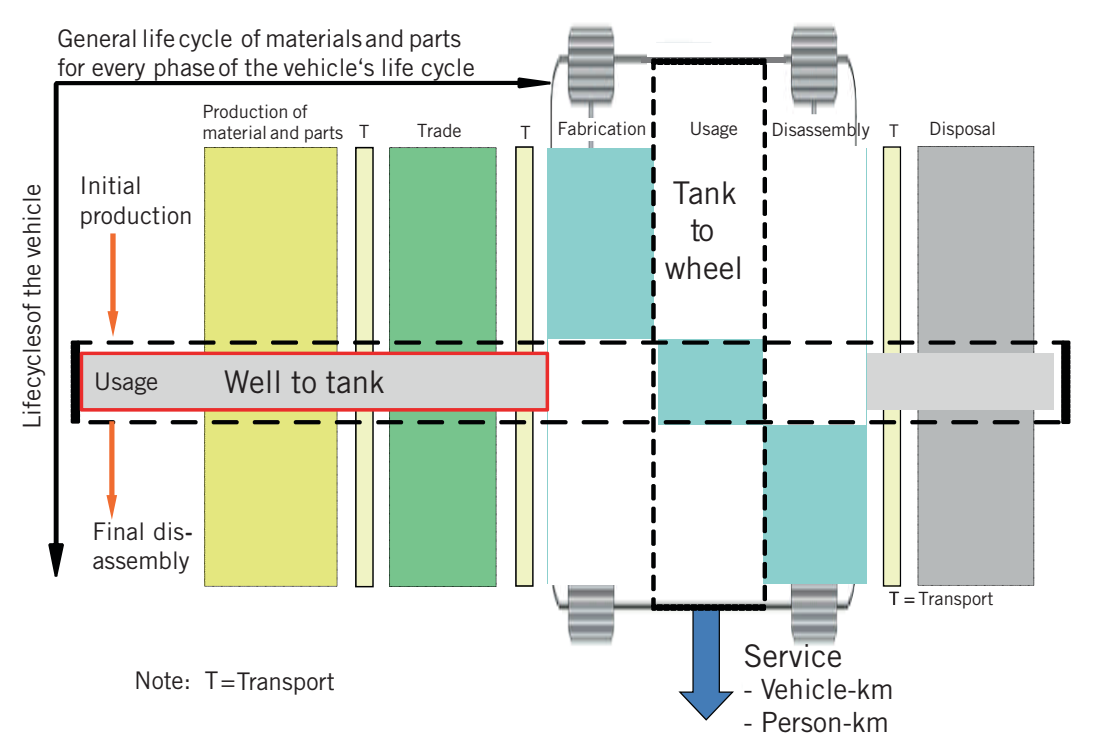

1 Darstellung der Prozessketten des Well-to-Tank- und des Tank-to-Wheel-Ansatzes auf Basis der horizontalen und vertikalen Systemgrenzen des Kraftfahrzeuglebenswegs [1] (die hier verwendeten Systemgrenzen sind rot eingerahmt)

Illustration of process chains of the well-to-tank and tank-to-wheel approach based on horizontal and vertical system boundaries of the vehicles' life cycle [1] (the used system boundaries are red framed) 


\section{SUSTAINABLE ENERGY SUPPLY OF MOBILE MACHINES}

The growing world population and the economic growth will cause the demand for energy to increase in the future. In order to meet this development, solutions follow a deeper search after resources of fossil energy carriers up to the development of complete new energy supply systems. Furthermore, politics try to pave the way into an energy supply based on renewable energy carriers through legal framework conditions. This scenario introduces several solutions for a sustainable energy supply of mobile machines, which was worked out at the chair for mobile machines at the KIT.

\section{SYSTEM BOUNDARIES FOR THE ASSESSMENT OF DRIVE CONCEPTS}

Within the scope of mobile machines, different energy supply systems and corresponding drive concepts are discussed to satisfy objectives of climate policy and price progression of exhaustible and conventional energy supply. The aim is to pave the way for an energy supply based on renewable energies, to reach the proclaimed $\mathrm{CO}_{2}$-emission limits and avoid high mineral oil prices. In this study different solutions for a sustainable energy supply of mobile machines are researched, starting from status quo to 2050. Definitions of the criteria of sustainability are made and employed on the present and the prospective energy supply. Today's electric drives don't cause local emissions. However, such emissions arise when generating electricity at a power plant. Therefore, a tank-towheel approach is insufficient. Due to this fact, a holistic approach in the sense of a well-to-wheel analysis is chosen to ensure a better comparability between drive systems, with and without direct emissions. An overview on the general system boundaries is given in 10 [1], displaying the life cycle of material and parts used for the vehicle on the horizontal axis and their timing of use on the vertical axis. Out of this general well-towheel approach, the system boundaries are adjusted for this study in the following way:

: Different energy supply systems will be compared to each other, so that the actual usage in the sense of operating time on the horizontal axis is irrelevant. Comparable machines with equal operating time are considered for the energy supply.

: On the vertical axis the spot is searched, when the machine uses one unit fuel or one unit of energy.

In production of material and parts, the production and preparation of the fuel/energy is considered only, not the production of the technology taking the final transformation to the transmission shaft (such as petrol and diesel engine, electric motor) or saving the energy along the path (batteries, storage power plant etc.).

The efficiencies of power storages are added wherever storage is necessary due to fluctuating energy availability. Overall, the system boundaries can be declared as well-to-tank including the energy transformation in the engine (1) framed red), dismantling disposal is not considered.

\section{DEFINITION OF A}

\section{SUSTAINABILITY INDEX}

The development of the energy paths gives an overview on possible energy supplies. The energy paths visualize the diversity of energy supply systems, 2 . From fossil and renewable energy sources, the energy is transformed along different paths and branches into exergy at the main engine (internal combustion engine, electric motor or hybrid drive system). The greater part of the energy path could be displayed and assessed by using data of ecoinvent. This database provides numerous datasets for numerous industrial processes to evaluate the life cycle cost they are causing (LifeCycle-Inventory, LCI) and to assess their impact (Life-Cycle-Assessment, LCA). The records are per process very large and difficult due to the sheer number of entries the accounting, for example, with over 500 entries for emissions into the air. The ReCiPe methodology summarises the process data and categorises it for example through their global warming potential. The calculation methods and used factors are defined as follows:

: Sustainable efficiency factor

$\left(\eta_{\text {sustainable }}\right)$ : The amount of energy of the final product (heating value or kilowatt hour power) is compared to the energy necessary along the energy path (e.g. production, transportation etc.). The aim of the path is the tank. This factor is multiplied with the system efficiency of involved components which are not implemented in the path. The following factor is defined (Eq. 1):
AUTHORS

DR.-ING. PHILLIP THIEBES was Senior Engineer and Assistant Head of the Chair of Mobile Machines at the Karlsruhe Institute of Technology (Germany).

DIPL.-ING. ANDREAS RÜDENAUER was Member of the Academic Staff at the Chair of Mobile Machines at the Karlsruhe Institute of Technology (Germany).

B. SC. SEBASTIAN SCHMIDT is academic assistant at the Chair of Mobile Machines at the Karlsruhe Institute of Technology (Germany). 


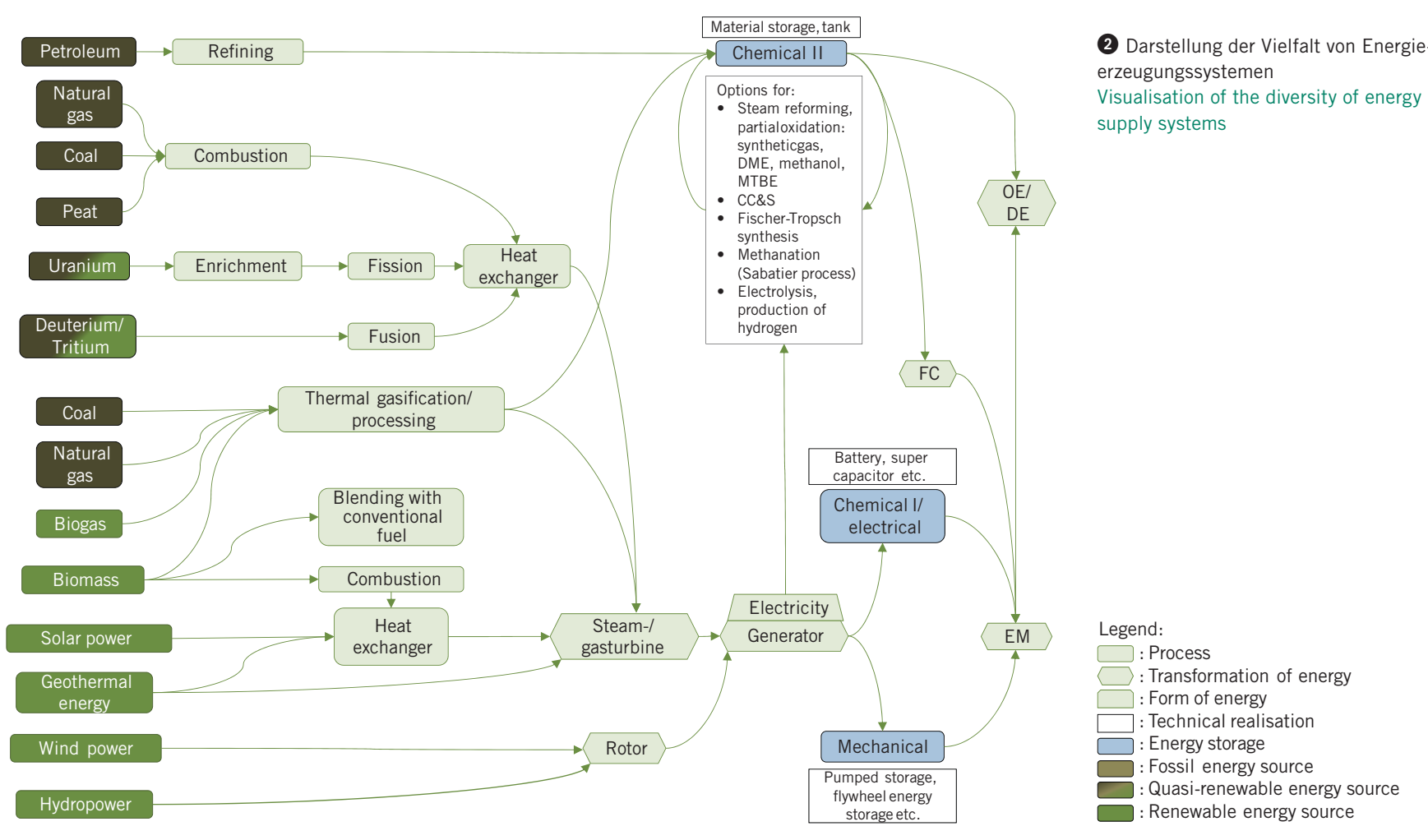

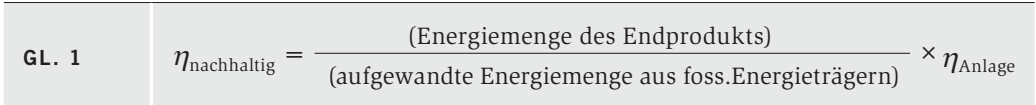

den Anlagenwirkungsgraden der beteiligten Komponenten, die nicht bereits im Pfad implementiert sind. Daraus ergibt sich folgende Definition (Gl. 1): Dabei stammt der Energieaufwand entlang des Pfades aus fossilen Energieträgern, die hier durch deren $\mathrm{CO}_{2}$-Emissionen als Kosten definiert werden. Die Werte werden aus der ecoinvent-Datenbank entnommen und durch ReCiPe auf Kilogramm Öl-Äquivalent oder Kilowattstunde umgerechnet.

$\mathrm{CO}_{2}$-Emissionen: $\mathrm{Zu}$ unterscheiden sind direkte und indirekte Emissionen. Bei direkten Emissionen werden nur die Emissionen berücksichtigt, die am Ort der Energieumwandlung auftreten, also zum Beispiel die Emissionen bei der Verbrennung von Dieselöl im Motor. Indirekte Emissionen berücksichtigen dagegen auch die bei der Gewinnung und Bereitstellung entstandenen Emissionen. Die Summe hieraus bildet die Gesamtemission von Treibhausgasen, umgerechnet auf Kilogramm $\mathrm{CO}_{2}$-Äquivalent pro Kilowattstunde Energie (Gl. 2):

\begin{tabular}{l|l}
\hline & Gesamtemission $=$ \\
GL. 2 & Emission $_{\text {direkt }}+$ Emission $_{\text {indirekt }}$
\end{tabular}

\section{BEWERTUNGSSCHRITTE DER HEUTIGEN UND ZUKÜNFTIGEN ENERGIEVERSORGUNG}

Die Bewertung erfolgt in drei Schritten. Zuerst wird die aktuelle Energieversorgung untersucht. Mobile Arbeitsmaschinen werden heute fast ausschließlich mit Dieselmotoren betrieben, vor allem bei größeren Maschinen in der Landwirtschaft, Forstwirtschaft und auf Baustellen. Kleinere Einheiten, wie beispielsweise Gabelstapler, werden durch Elektromotoren oder gasbefeuerte Ottomotoren angetrieben. Kleinere, mit Ottokraftstoff befeuerte Maschinen, wie Rasenmäher, Motorsägen oder Trimmer, werden hier nicht berücksichtigt. Die Suche nach Lösungen für die Zukunft erfolgt nach zwei Ansätzen:

: Versorgung mit aktueller Technologie: Hierbei werden die aktuell möglichen Technologien übersichtlich dargestellt und nach den oben genannten Kriterien bewertet. Insbesondere wird hierbei auf biogene Kraftstoffe eingegangen, beispielsweise die Herstellung von Biodiesel und Bioethanol, aber auch eine alternative Nutzung konventioneller Primärenergieträger soll auf Nachhaltigkeit überprüft werden.
: Versorgung mithilfe zukünftiger Technologien: Dieser Abschnitt beantwortet die Fragen nach den Perspektiven von Technologien, die heute noch eine zu geringe Wirtschaftlichkeit und Effizienz aufweisen, in Zukunft aber eine gewichtige Rolle für Durchbrüche bei der Energieversorgung einnehmen können. Ausgehend vom aktuellen Entwicklungsstand werden die $\mathrm{Zu}$ kunftsaussichten unter anderem in den Bereichen der Batterietechnik, Brennstoffzellentechnik und den Biokraftstoffen der zweiten Generation hier kurz erwähnt.

\section{ENERGIESPEICHER UND TECHNOLOGIEPERSPEKTIVEN}

Zuerst einmal stellt sich die Frage, wie die $\mathrm{CO}_{2}$-Faktoren (also die direkten Emissionen) bei der Verbrennung biogener Kraftstoffe in die Bewertung einfließen. Laut [2] emittieren Biokraftstoffe $\mathrm{CO}_{2}$, dies jedoch nur in der Menge, in der es die pflanzlichen Rohstoffe zuvor im Wachstum aus der Atmosphäre gebunden haben. Daher werden die direkten Emissionen bei der Verbrennung biogener Kraftstoffe vernachlässigt und nur die indirekten Emissionen betrachtet. Bei einem Wert von $100 \%$ wurde genau die aufwandte Energie aus fossilen Energieträgern durch den Nutzen aus regenerativen Energieträgern kompensiert. Dies ist 


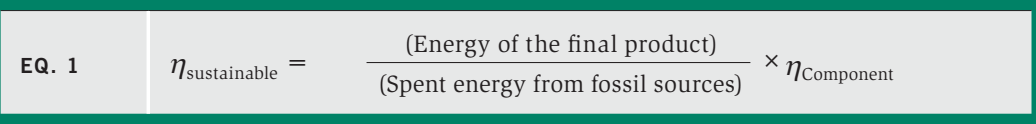

The energy needed along the path origins from fossil fuel sources and is defined as a cost due to their $\mathrm{CO}_{2}$-emission. The data derives from the ecoinvent database and is summarised with ReCiPe to kilogram oil-equivalent or kilowatt hour.

$\mathrm{CO}_{2}$-emission: Direct and indirect
emissions are to be differentiated. Emissions which occur at the spot of the final energy conversion are considered as direct emissions, e.g. while combusting diesel oil in the engine. Emissions which occur through production, transportation etc. along the path are considered as indirect emissions. The sum of direct and indirect emissions is the total emission of Greenhouse gases, converted to $\mathrm{CO}_{2}{ }^{-}$ equivalents per kilowatt hour energy:

\section{APPROACHES TO ASSESS THE PRESENT AND PROSPECTIVE ENERGY SUPPLY}

The assessment is made in three steps. The present energy supply will be analysed first. Mobile machines operate mainly with diesel, especially large machines in agriculture, forestry and on construction sites. Some small machines use electricity or gas-fired Otto engines, such as fork lift trucks. Hand held units like lawnmowers, chainsaws or trimmers are not within this study's scope. The solution for the prospective energy supply is found by two approaches:

Supply with present technology:

Today's possible technologies are presented and evaluated, using the described criteria. Biogenic fuels are considered, e.g. the production of biodiesel and bioethanol as well as an alternative usage of fossil fuels will be checked on its sustainability.

Supply with future technology: This section gives an outlook on technologies, which are not profitable or efficient just yet, but may well have an impact on the prospective energy supply. The chances of battery technology, fuel cell technology and the second generation of biofuels are briefly mentioned, based on the recent state of the art.

\section{ENERGY STORAGE AND TECHNOLOGY PROSPECTS}

First of all it has to be defined, how $\mathrm{CO}_{2}$-factors (direct emissions) are being considered, when combusting biogenic fuels. According to [2], biofuels emit $\mathrm{CO}_{2}$, but merely the amount they have captured from the atmosphere while growing. Therefore, direct emissions from combustion of biogenic fuels are not taken into account, but indirect emissions. At the value of $100 \%$, the used energy from fossil fuels is compensated by the renewable energy. This is possible because the energy coming from renewable energies is not regarded as a cost in the denominator. The use coming from renewable energies is bigger than the cost coming from fossil energies when exceeding the value of $100 \%$. Further efforts in research and development ( R \& D) of energy storage are necessary to realise the discussed energy path in the future. Until now, the focus in R \& D lies mainly on storing electrical energy using batteries, since the biggest potential is expected there [3]. A large scale electrification of vehicle fleets and mobile machines is currently failing due to high prices of the used materials for the batteries and their low energy density compared to fossil fuels. An overview about country-specific aims gives [3]. The general aim is to increase the energy density by $250 \%$ while reducing the today's price to one fifth until 2020. Lithium sulphur batteries are considered to improve the energy density by factor four when produced optimally. This technology will be available probably in 2020 but not realistically in vehicles before 2030. An efficiency of $75 \%$ is estimated, uncertainty lies in safety and lifetime. After solid-state lithium ion batteries and lithium polymer batteries, the development of a lithium air battery is expected as from 2030, where the biggest potentials in improving the mass-specific energy density are assumed [3]. In [4], a roadmap for the introduction of lithium ion batteries in different sectors is made.
For hybrid drive concepts, lithium sulphur and lithium polymer batteries seem to be a medium-term solution, the lithium air technology may be a promising solution for the complete electrification. The development of the fuel cell technology will be a matter of cost, if the power to gas path with hydrogen is followed. Pressure reservoirs with lower masses and a distribution infrastructure analogous to the present petrol station network would be necessary. According to [3], there won't be a fuel cell in the future, renouncing the expensive platinum. Compared to batteries, the energy density is better (compare heating value hydrogen) and the refuelling time acceptably short (about three minutes) resulting in larger ranges. Whether the life time of a fuel cell powertrain can cover the life time of mobile machines, should be analysed separately. Biofuels have a limited potential because of their possible competition with the food industry and their limited area for planting energy crops. By mixing biofuels to conventional fuels and with the development to utilise woody crops and the usage of waste and recycling material, biofuels though pave the way into a sustainable energy supply [1]. Further developments regarding drive concepts can be found in [5].

\section{RESULTS}

The results in $\mathbf{3}$ show, that the power generation from renewables with utilisation in an electric motor is promising. 4 shows the relevant energy paths. It should be noted that there is nearly no further potential for improvement seen for the highest ranking energy supply in (3), power from hydropower-mix. For other renewables energies with an expected increase, such as wind power and photovoltaic, the problem of storing fluctuating power remains unsolved. For electricity storage, batteries may be considered as well as the transformation into storable gases like hydrogen or methane or mechanical storage with pumped storage power plants. Commercial solutions for power to gas don't exist yet. The energy paths for power-to-gas are displayed in 5. Power to hydrogen has a larger sustainable efficiency factor than power to methane. Individual power to methane path (from hydropower-mix and wind power-mix) show 
möglich, da die aus regenerativen Energieträgern entstammende Energie nicht als Verbrauch im Nenner gezählt wird. Beträgt der Wert somit mehr als $100 \%$, ist der Nutzen aus regenerativen Energieträgern größer als der Aufwand aus fossilen Energieträgern. Um die diskutierten Energiepfade der Zukunft zu realisieren, sind weitere Bemühungen in Forschung und Entwicklung ( $F$ \& E) bezüglich der Energiespeicherung nötig. Bislang ist hauptsächlich die Speicherung elektrischer Energie in Batterien im Blickpunkt von F \& E, da hier die größten Potenziale vermutet werden. Eine großtechnische Elektrifizierung von Fahrzeugflotten und Arbeitsmaschinen scheitert bisher an den hohen Kosten für die verwendeten Materialien sowie der relativ geringen Energiedichte gegenüber fossilen Energieträgern. Eine Übersicht zu den gesteckten Zielen führender Länder gibt [3]. Allgemeine Zielsetzung ist eine Verbesserung der Energiedichte um 250 \% bei einem Fünftel des heutigen Preises im Jahre 2020. Konkret stellen LithiumSchwefel Batterien eine um den Faktor vier verbesserte Energiedichte bei bestmöglicher Verarbeitung in Aussicht. Diese Technologie soll ab 2020 verfügbar sein, realisierbar in Elektrofahrzeugen aber nicht vor 2030 [3]. Hier wird ein Wirkungsgrad von $75 \%$ geschätzt, Unwägbarkeiten finden sich bei Sicherheit und Lebensdauer. Nach LithiumFeststoff- und Lithium-Polymer-Systemen wird für die Zeit ab 2030 die Entwicklung einer Lithium-Luft-Batterie erwartet, wofür die mit Abstand größten Potentiale zur Verbesserung der massenspezifischen Energiedichte vermutet werden. In [4] wurden Prognosen für die Einführung der Lithium-Ionen Batterien in unterschiedlichen Zielbereichen in Form einer Roadmap hinterlegt. Für die Lithium-Ionen-Technologie ist die Roadmap in [4] dargestellt. Für hybride Antriebskonzepte scheinen LithiumSchwefel- und Lithium-Polymer-Batterien mittelfristige Lösungen zu sein, für eine vollständige Elektrifizierung könnte die Lithium-Luft-Technologie eine vielversprechende Lösung sein. Für die Entwicklung der Brennstoffzellen-Technologie stellt sich vor allem die Kostenfrage, falls man den Power-to-gas-Pfad mit Wasserstoff verfolgen möchte. Notwendig wären hierfür Druckspeicher mit geringerer Masse und eine Verteilerinfrastruktur entsprechend dem heutigen

\begin{tabular}{|c|c|c|}
\hline NAME OF THE ENERGY PATH & $\eta$ SUSTAINABLE [\%] & $\begin{array}{l}\text { TOTAL EMISSIONS } \\
\left.\text { [KG } \mathrm{CO}_{2} / \mathrm{KWH}\right]\end{array}$ \\
\hline 1. Electricity from hydropower-mix (in EM) & 8436 & 0.0075 \\
\hline 2. Biomethanol from synthetic gas (in DE) & 3156 & 0.0016 \\
\hline 3. Electricity from wind power-mix (in EM) & 2172 & 0.0127 \\
\hline 4. Electricity from combusting wood (in EM) & 974 & 0.0318 \\
\hline 5. Electricity from biogas from CHP (in EM) & 454 & 0.5222 \\
\hline 6. Power to hydrogen from hydropower-mix (in FC+EM) & 409 & 0.0531 \\
\hline 7. Electricity from PV-mix (in EM) & 286 & 0.0953 \\
\hline 8. Electricity from biogas-mix (in SOFC-GT) & 276 & 0.7198 \\
\hline 9. Electricity from biogas-mix (in SOFC) & 234 & 0.8449 \\
\hline 10. Power to hydrogen from wind power (in FC+EM) & 232 & 0.0695 \\
\hline 11. Biomethanol from biomass (in DE) & 208 & 0.0578 \\
\hline 12. Biomethane from biosgas-mix (in OE) & 182 & 0.3637 \\
\hline 13. Biodiesel from vegetable oil (in DE) & 175 & 0.0409 \\
\hline 14. Ethanol from sugar cane (in OE) & 159 & 0.1019 \\
\hline 15. Power to methane from hydropower-mix (in OE) & 156 & -0.1680 \\
\hline 16. Biodiesel from palm oil (in DE) & 132 & 0.1866 \\
\hline 17. Ethanol from wood (in OE) & 130 & 0.1083 \\
\hline 18. Biodiesel from soybean oil (in DE) & 120 & 0.7124 \\
\hline 19. Ethanol from sugar beet (in OE) & 118 & 0.101 \\
\hline 20. Ethanol from sorghum (in OE) & 98.67 & 0.1156 \\
\hline 21. Hydrogen from naphta (in FC+EM) & 92.40 & 0.076 \\
\hline 22. Power to methane from wind power (in OE) & 88.01 & -0.1483 \\
\hline 23. Power to hydrogen from biogas-mix (in FC+EM) & 72.25 & 16793 \\
\hline 24. Biodiesel from rapeseed oil (in DE) & 69.13 & 0.2683 \\
\hline 25. Electricity from diesel oil via CHP (in EM) & 53.88 & 0.4357 \\
\hline 26. Power to hydrogen from PV-mix (in FC+EM) & 47.76 & 0.3305 \\
\hline 27. Electricity from natural gas via SOFC-GT (in EM) & 47.49 & 0.5098 \\
\hline 28. Electricity-mix (in EM, present) & 46.12 & 0.4342 \\
\hline 29. Electricity from natural gas via SOFC (in EM) & 40.45 & 0.5985 \\
\hline 30. Ethanol from rye (in OE) & 38.28 & 0.3196 \\
\hline 31. Ethanol from corn (in OE) & 36.81 & 0.3012 \\
\hline 32. Diesel oil (in DE, present) & 35.39 & 0.3304 \\
\hline 33. Natural gas (in $\mathrm{OE}$, present) & 28.31 & 0.2677 \\
\hline 34. Power to methane from biogas-mix (in OE) & 27.48 & 17818 \\
\hline 35. Methanol from natural gas (in DE) & 24.08 & 0.1693 \\
\hline 36. Autogas (in OE, present) & 23.84 & 0.3356 \\
\hline 37. DME (in DE) & 21.35 & 0.2322 \\
\hline 38. Power to methane from PV-mix (in OE) & 19.20 & 0.1646 \\
\hline
\end{tabular}

3 Ergebnisse und Rangfolge der Energiepfade (EM: Elektromotor, DM: Dieselmotor, OM: Ottomotor, BZ: Brennstoffzelle, SOFC: Festoxidbrennstoffzelle, GT: Gasturbine, BHKW: Blockheizkraftwerk) Results and ranking of the energy paths (EM: Electric motor, DE: Diesel engine, OE: Otto engine, FC: Fuel cell, SOFC: Solid oxide fuel cell, GT: Gas turbine, CHP: Combined heat power unit)

Tankstellennetz. Außerdem wird es laut [3] auch zukünftig keine Brennstoffzelle geben, die auf den teuren Rohstoff Platin vollständig verzichtet. Zu den Vorteilen gegenüber Batterien gehören der größere Energieinhalt im Tank (vergleiche Heizwert Wasserstoff), die daraus resultierende größere Reichweite sowie die geringe Dauer des Tankvorgangs von etwa drei Minuten. Ob mit der Lebensdauer eines Brennstoffzellenantriebs die Lebensdauer einer mobilen Arbeitsmaschine abgedeckt werden kann, ist noch in weitergehenden Betrachtungen zu untersuchen. Biokraftstoffe besitzen durch ihre potenzielle Konkurrenz zur Nahrungsmittelproduktion und durch die limitierte Fläche für den Anbau von Energiepflanzen ein begrenztes Potenzial. Durch das Mischen zu konventionellen Treibstoffen, den Entwicklungen zur Verwertung holzartiger Pflanzen und der Verwendung von Rest- und Abfallstoffen bilden Biokraftstoffe dennoch einen Einstieg in eine nachhaltige Energieversorgung [1]. Für weitere Entwicklungen bezüglich Antriebstechnologie und Energiespeicherung wird auf [5] verwiesen.

\section{ERGEBNISSE}

Die Ergebnisse in 3 zeigen, dass eine direkte Stromerzeugung aus den Erneu- 
negative emission results because carbon dioxide is absorbed for methanation. Here, a further investigation how much energy is used to provide pure carbon dioxide is recommended. This technology would be ecologically reasonable, moreover it uses the advantage of an existing infrastructure for methane storage. The two paths power to methane from biogas-mix and photovoltaic don't represent an improvement in terms of the sustainable efficiency factor compared to today's solutions. Furthermore the path from biogas-mix has clearly worse emission results. These two paths don't seem to be reasonable solutions for the future, despite the technological improvement. The utilisation of waste wood gives good sustainable efficiency factors because there is only an effort in gathering and combusting. The production of synthetic methanol via wood gasification and the direct combustion is plausible as well. Possibilities to produce synthetic fuels shows 6. Compared to hydropower, the same problems occur with the path including wood: The limited potential. The path electricity from biogas delivers good values, either via a combined heat power unit or by combusting directly in a fuel cell (or a mini gas turbine) on the machine. If the life time of fuel cells increases, this path will be a good alternative due to a high sustainable efficiency factor but on a high emission level. The synthetic production of biomethanol reaches a high factor as well with much lower emissions. Most of the paths with biodiesel and ethanol have a sustainable efficiency factors above $100 \%$, so more use than cost comes up. Merely the path via rapeseed, rye and corn reveal worse values. A chance to switch to other biomasses or synthetic production processes is introduced to invalidate the food or fuel discussion. Now, a scenario can be made by using all this information. Because of the large potentials in wind power and photovoltaic plus the promising developments and ambitious aims in the battery technology, the path electricity from wind power/photovoltaic, in electric motor via storage in a battery appears to be a path with good chance of success in the future. Item 3 is given preference, because the first two items will play a minor role in the future due to their small potential. Concerning the storage, an optimistic look can be taken into the future: With high investments and the global competition, a progression of the energy density of lithium ion batteries up to $250 \%$ until 2020 with a cost reduction at the same time is realistic. The best way to utilise biomass (except biodiesel and bioethanol) is not the gasification to biogas, and therefore not the path electricity from biogas, but the synthetic production of biomethanol. This path is the only one improving the emission level, every other path is on the same or a higher level compared to today's energy path. The advantage of this technology lies in the simple storage and the use of existing infrastructure (distribution, petrol stations etc.). The power to gas technology with wind power forms a low emitting way to drive mobile machines as well, especially since hydrogen needs small tank volumes because of its high heating value. Necessary for that are improvements concerning the storage efficiency and the infrastructure but also in the commercial production of the gases. Until 2050, it seems to be realistic that in the course of the further development of the fuel cell technology, those issues will decrease and the technology will become an appropriate alternative or complementary technology to the battery electric supply due to the high life time. The results also show, that the first generation of biofuels is an appropriate alternative for petrol and diesel fuels, which can lead the way into a renewable energy supply. The selection, which energy crops shall be cultivated, can be made using the emission values. The potentials for this generation of biofuels are limited through the land use, a transfer to the second or even the third generation of land specific energy density makes sense. This paper has also shown that there are better solutions regarding sustainable efficiency factors compared to today's solutions. But the objective must be to lower the arising emissions per kilowatt hour provided energy with new alternatives compared to today's solutions.

\section{SUMMARY AND OUTLOOK}

Within the system boundaries well to tank including the efficiencies for the energy conversion on the transmission shaft, several energy paths to supply mobile machines were investigated. Hereby, the works' focus was set on a prospective drive concept. The energy paths were analysed on the basis of selfdefined sustainability criteria. In doing so, the sustainable efficiency factor and the total emission, converted into $\mathrm{CO}_{2}$ equivalents, were determining, the consideration of land usage and water expenditure will get in public focus in the future, due to the rising world population and the accompanied increase of the natures' usage. With the aid of the database ecoinvent and the integrated assessment method ReCiPe, the present and prospective possible energy paths were depicted and data was allocated to the criteria. Thereof, a ranking of paths was made, which were sortedin descending order by their sustainable efficiency factor. It showed, that the power generation from photovoltaic and wind power have a big development potential, a high sustainable efficiency factor and low $\mathrm{CO}_{2}$-emissions. Using batteries and the transformation to storable gases, this fluctuating, incoming electrical energy shall be stored. However, the power-togas paths showed that only the paths with wind and hydropower show an improvement compared to present energy carriers. For hydropower, the development potentials, at least in Germany, are limited and therefore, a growing share of hydropower in the energy mix is not expected. Until now, the technologies of batteries and power-to-gas fail because of their high costs, the large scale production and the demands of mobile machines. Another good alternative is the usage of biomass and their conversion to substitutes of present fuels (such as biodiesel made of vegetable oil and bioethanol from sugarcane) and biomethanol. The advantages of these paths is the products' utilisation in conventional combustion engines, the development potential is through their land use limited as well. In the short and medium term, the way into a renewable energy supply can be paved by biomass, until the technologies of batteries and fuel cells can meet the demands of mobile machines.

Due to their research time, the fundamental question may be asked to what extent the present combustion engines can be compared to batteries and fuel cells. For more than 150 years, combustion engines are part of intense research. Future relevant technologies gain an increased interest for 10 years, so that 
erbaren mit einer Stromverwertung im Elektromotor vielversprechend ist. 4 gibt hierfür einen Überblick über die Energiepfade. Zu bemerken ist, dass für Platz 1 in (3) die Potenziale in Deutschland weitestgehend ausgeschöpft sind. Für die anderen erneuerbaren Energien mit hohen Zuwachspotenzialen, wie Windkraft und Photovoltaik, besteht weiterhin das Speicherproblem durch die fluktuierende Stromerzeugung. Für die Speicherung von Strom bieten sich hier neben Batterien auch die Umwandlung in speicherbares Gas, wie Wasserstoff und Methan, oder größere mechanische Speicher, wie Pumpspeicherkraftwerke, an. Für die Power-to-gas-Technologien existieren derzeit noch keine großtechnischen Lösungen. Die Power-to-gas-Pfade sind in 5 abgebildet. Power-to-hydrogen hat hierbei einen größeren nachhaltigen Wirkungsgrad als Power-to-methane. Einzelne Power-to-methane-Pfade (aus Wasserkraft- und Windkraft-Mix) weisen eine negative Emissionsbilanz auf, da für die Methanisierung Kohlenstoffdioxid gebunden (verbraucht) wird. Hier ist eine weiterführende Untersuchung der benötigten Energiemengen zur Bereitstellung von reinem Kohlenstoffdioxid sinnvoll. Ökologisch wäre diese Technologie durchaus sinnvoll, außerdem bietet sich der Vorteil einer bereits bestehenden (Speicher-)Infrastruktur für Methan an. Die beiden Pfade Power-to-methane aus Biogasmix und Photovoltaik stellen gegenüber den heutigen Lösungen hinsichtlich des nachhaltigen Wirkungsgrades keine Verbesserung dar, außerdem besitzt der Pfad aus Biogasmix eine deutlich schlechtere Emissionsbilanz. Diese beiden Pfade scheinen trotz der technologischen Fortentwicklung keine sinnvollen Lösungen für die Zukunft zu sein. Gute nachhaltige Wirkungsgrade ergeben sich bei der Verwertung von Restholz, da hier nur ein Aufwand bezüglich des Sammelns und Verbrennens besteht. Die Herstellung von synthetischem Methanol über Holzvergasung und auch die direkte Verbrennung bieten sich an. Die Möglichkeiten der synthetischen Kraftstoffe zeigt 6 . Für die Pfade mit Holz bestehen die gleichen Probleme wie mit Wasserkraft: Das begrenzte Potenzial. Gute Werte liefert der Pfad Strom aus Biogas, entweder über ein Blockheizkraftwerk oder durch eine direkte Verwertung des Gases in Brennstoffzellen (beziehungsweise inklusive Minigastur-

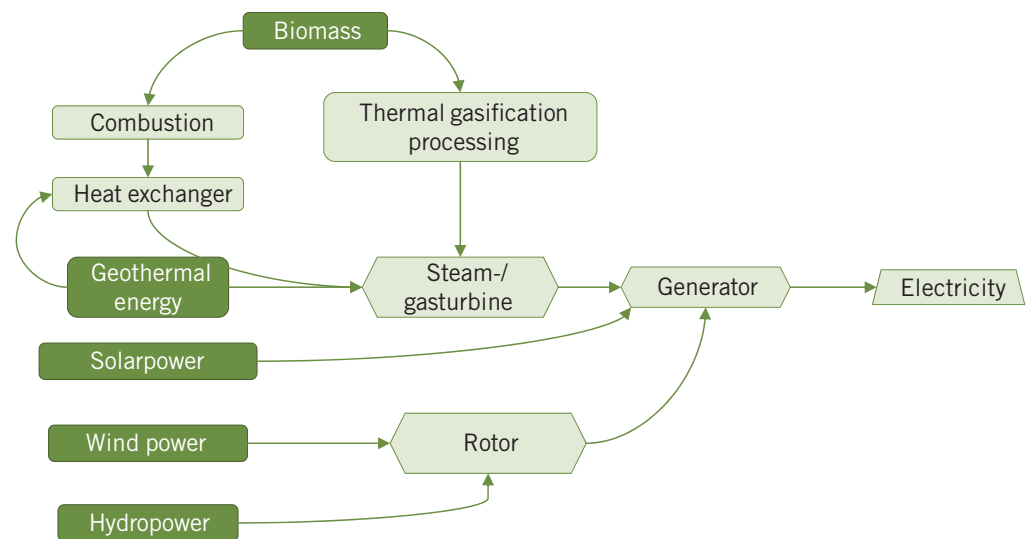

(4) Energiepfade zur Stromerzeugung aus erneuerbaren Energieträgern Energy paths for power generation using renewable energy carriers

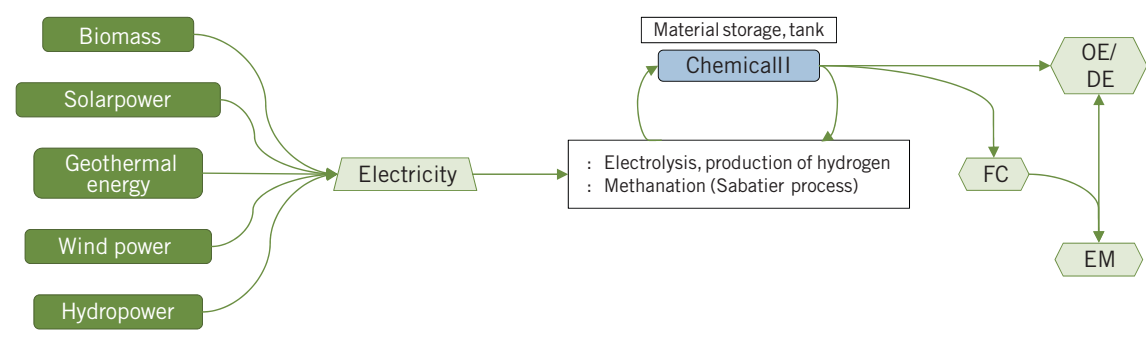

(5) Energiepfade zur chemischen Speicherung erneuerbarer Energie Energy paths for the chemical storage of renewable energy

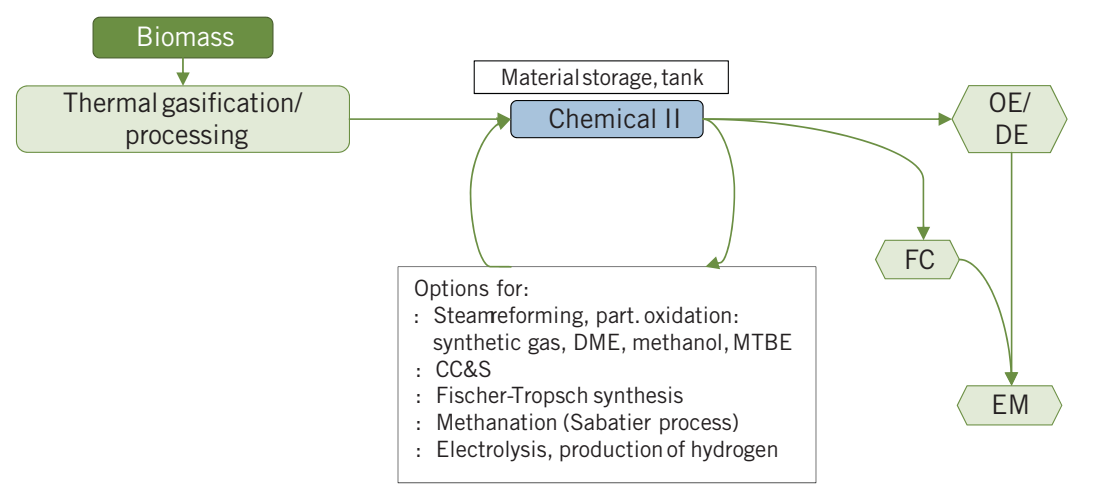

6 Energiepfade für die synthetische Herstellung von Kraftstoffen aus Biomasse Energy paths for the synthetic production of fuels out of biomass

bine) auf der Maschine. Falls sich die Lebensdauer von Brennstoffzellen weiter steigern, stellt dieser Pfad eine gute Möglichkeit durch gute Wirkungsgrade, aber auf höherem Emissionsniveau dar. Die synthetische Herstellung von Biomethanol erreicht ebenfalls einen guten nachhaltigen Wirkungsgrad, jedoch sind die hierbei anfallenden Emissionen deutlich niedriger. Die meisten Pfade mit Biodiesel und Ethanol besitzen einen nachhaltigen Wirkungsgrad über $100 \%$, es entsteht also mehr Nutzen als Aufwand.
Lediglich die Pfade über Raps, Roggen und Mais weisen schlechtere Werte aus. Dadurch eröffnet sich eine Chance auf andere Biomassen umzusteigen oder synthetische Herstellungsverfahren zu nutzen, um die Tank- oder Teller-Problematik zu entkräften. Aus diesen Daten soll nun ein Szenario entwickelt werden. Durch die großen Ausbaupotenziale für Windkraft und Photovoltaik sowie die vielversprechenden Entwicklungen und ehrgeizigen Zielsetzungen in der Batterietechnik erscheint der Pfad Strom aus 
the development potential can be highlighted because of their handling time. For further research, the importance of system boundaries may be emphasised. If the usage of energy and the emissions is added for instance to produce batteries and engines or the construction of a pumped storage power plant, the result will change. Furthermore, temporal parameters have to be added. To gain absolute values for a holistic well- towheel analysis the energy consumption and the emissions while operating the

\section{REFERENCES}

[1] Buchgeister, J.: Das relevante System zur

Bewertung von Antriebskonzepten. Tagungsbeiträge

vom 08.-09.03.2012 am Karlsruher Institut für

Technologie (KIT), KIT Scientific Publishing 2013,

pp. 109-121

[2] http://biokraftstoffe.fnr.de/kraftstoffe/ein-

fuehrung/. Abgerufen am 13.09.2013

[3] Fraunhofer ISI: Technologie-Roadmap Energie-

speicher für die Elektromobilität 2030. 2012

[4] Fraunhofer ISI: Technologie-Roadmap Lithium-

Ionen-Batterien 2030. 2010

[5] Schmidt, S.: Nachhaltige Energieversorgung

Mobiler Arbeitsmaschinen im Jahre 2050.
Wind/Photovoltaik, in Elektromotor mit Speicherung in einer Batterie, als ein Pfad mit guten Erfolgsaussichten für die Zukunft. Damit wird Platz drei der Vorzug gegeben, da die beiden ersten Plätze durch ihr geringes Ausbaupotenzial in Zukunft nur eine untergeordnete Rolle einnehmen werden. Hinsichtlich der Speicherung kann man optimistisch in die Zukunft sehen: Durch die hohen Investitionen und die globale Konkurrenz ist eine Steigerung der Energiedichte Lithium-basierter Batterien bis zu $250 \%$ bis 2020 bei gleichzeitiger Kostenreduktion realistisch. Entwickelt sich die deutsche Netzinfrastruktur wie von der Bundesregierung gewünscht, steht der elektrischen Versorgung mobiler Arbeitsmaschinen bezüglich des nachhaltigen Wirkungsgrades in Deutschland zukünftig nichts im Weg. Die beste Möglichkeit zur Verwertung von Biomasse (ausgenommen Biodiesel und Bioethanol) ist nicht die Vergasung zu Biogas, also auch nicht die Pfade Strom aus Biogas, sondern die synthetische Herstellung von Biomethanol. Dieser Pfad stellt als einziger eine Verbesserung hinsichtlich der Emissionen dar, alle anderen befinden sich auf demselben oder einem höheren Emissionsniveau im Vergleich zu den heutigen Energiepfaden. Der Vorteil dieser Technologie liegt in der einfachen Speicherbarkeit sowie der Nutzung bestehender Infrastruktur (Distribution, Tankstellen etc.). Ebenso bildet die Power-to-gas-Technologie aus Windkraft eine emissionsarme Möglichkeit für den Antrieb mobiler Arbeitsmaschinen, da vor allem Wasserstoff einen hohen Heizwert aufweist und daher ein geringes Tankvolumen benötigt. Notwendig dafür sind deutliche Verbesserungen hinsicht- lich des Speicherwirkungsgrades sowie der Infrastruktur, aber auch bei der großtechnischen Herstellung der Gase. Bis 2050 scheint es realistisch, dass im Zuge der Weiterentwicklung der Brennstoffzellentechnik diese Problematik verkleinert wird und damit durch die hohe Lebensdauer zu einer geeigneten Alternative beziehungsweise komplementären Technologie zur batterieelektrischen Versorgung wird. Die Ergebnisse zeigen auch, dass die Biokraftstoffe der ersten Generation eine geeignete Alternative für Otto- und Dieselkraftstoff darstellen und den Übergang in eine erneuerbare Energieversorgung ebnen können. Die genaue Auswahl für den Anbau von Energiepflanzen kann anhand der Emissionswerte ermittelt werden. Die Potenziale für diese Generation von Biokraftstoffen sind durch ihre Landnutzung begrenzt, eine Verlagerung in Richtung der zweiten oder möglichen dritten Generation für eine Erhöhung der flächenspezifischen Energiedichte ist zukünftig daher sinnvoll. Diese Arbeit zeigt auch, dass es bezüglich des nachhaltigen Wirkungsgrades bessere Lösungen als die heutigen gibt. Ziel muss auch sein, die anfallenden Emissionen pro Kilowattstunde bereitgestellter Energie bei neuen Alternativen geringer zu halten als bei den heutigen Lösungen.

\section{ZUSAMMENFASSUNG UND AUSBLICK}

Innerhalb der Systemgrenzen well-totank inklusive der Wirkungsgrade für die Energieumsetzung auf die Getriebeeingangswelle wurden verschiedene Energiepfade zur Energieversorgung mobiler Arbeitsmaschinen untersucht. Dabei richtete sich der Blickpunkt der Arbeit auf ein zukünftig zu realisierendes Antriebssystem. Die Energiepfade wurden anhand von selbst definierten Nachhaltigkeitskriterien untersucht. Dabei waren der nachhaltige Wirkungsgrad und die Gesamtemissionen umgerechnet auf $\mathrm{CO}_{2}$-Äquivalente entlang des Pfades ausschlaggebend, zukünftig werden die Betrachtung von Landnutzung und Wasserverbrauch durch die steigende Weltbevölkerung und die damit einhergehende Ausweitung der Nutzung der Natur in den Fokus der Öffentlichkeit geraten. Mithilfe der Datenbank ecoinvent und der integrierten Bewertungsmethode ReCiPe wurden die heutigen und einige zukünftig möglichen Energiepfade abgebildet und Daten den Kriterien zugeordnet. Daraus ergab sich eine Rangfolge an Pfaden, welche absteigend nach dem nachhaltigen Wirkungsgrad sortiert wurden. Hier zeigte sich, dass vor allem die Stromerzeugung aus Windkraft und Photovoltaik große Ausbaupotenziale, einen hohen nachhaltigen Wirkungsgrad und geringe $\mathrm{CO}_{2}$-Emissionen aufweist. Mithilfe von Batterien und der Umwandlung zu speicherbaren Gasen soll diese fluktuierend anfallende elektrische Energie gespeichert werden. Für die Power-togas-Pfade zeigten allerdings nur die Pfade mit Wind- und Wasserkraft bessere Ergebnisse gegenüber den heutigen Energieträgern. Für Wasserkraft sind die Ausbaupotenziale zumindest innerhalb Deutschlands erschöpft, somit ist mit einem steigenden Wasserkraftanteil am Energiemix nicht zu rechnen. Bislang scheitern die Technologien von Batterien und power-to-gas unter anderem an den hohen Kosten, der großtechnischen Produktion und den Anforderungen einer 
Arbeitsmaschine. Eine weitere gute Möglichkeit ist die Verwendung von Biomasse und deren Umwandlung zu Substituten aktueller Kraftstoffe (beispielsweise Biodiesel aus Pflanzenöl oder Ethanol aus Zuckerrohr) und Biomethanol. Vorteilhaft an diesen Pfaden ist die Verwertung der Produkte in konventionellen Motoren, durch die Landnutzung sind aber auch hier die Wachstumspotenziale begrenzt. Kurz- und mittelfristig kann durch Biomasse der Weg in eine regenerative Energieversorgung geebnet werden, bis die Technologien aus der Batterie- und Brennstoffzellentechnik den Anforderungen Mobiler Arbeitsmaschinen genügen.

Es stellt sich die grundlegende Frage, inwieweit heutige Verbrennungsmotoren mit Batterien oder Brennstoffzellen aufgrund ihrer Forschungszeit vergleichbar sind. An Verbrennungsmotoren wird seit über 150 Jahren durchgehend intensiv geforscht. Dagegen erfahren die zukünftig relevanten Technologien erst seit etwa 10 Jahren ein gesteigertes Interesse, sodass hier allein aufgrund der Bearbeitungszeit das große Entwicklungspotenzial für diese Technologien herausgestellt wird. Für weitere Betrachtungen sei die Wichtigkeit der Systemgrenzen hervorgehoben. Bezieht man noch die Endenergieaufwände und Emissionen, beispielsweise für die Produktion von Batterien und Motoren oder für den Bau eines Pumpspeicherkraftwerks, mit ein, können sich die Werte ändern. Außerdem müssten zeitliche Faktoren mit eingerechnet werden, für absolute Werte einer ganzheitlichen Well-to-wheel-Betrachtung sind die Energieverbräuche und Emissionen während des Betriebs der Maschine zu berücksichtigen.

\section{LITERATURHINWEISE}

[1] Buchgeister, J.: Das relevante System zur Bewertung von Antriebskonzepten. Tagungsbeiträge vom 08.-09.03.2012 am Karlsruher Institut für Technologie (KIT), KIT Scientific Publishing 2013, S. 109-121

[2] http://biokraftstoffe.fnr.de/kraftstoffe/einfuehrung/. Abgerufen am 13.09.2013

[3] Fraunhofer ISI: Technologie-Roadmap Energiespeicher für die Elektromobilität 2030. 2012

[4] Fraunhofer ISI: Technologie-Roadmap LithiumIonen-Batterien 2030. 2010

[5] Schmidt, S.: Nachhaltige Energieversorgung Mobiler Arbeitsmaschinen im Jahre 2050. Karlsruhe, KIT, Bachelorarbeit, 2013 